\title{
Organizational and Managerial Mechanism for Risk Management of Agricultural Enterprises
}

\author{
Karine Barmuta ${ }^{1, *}$ and Nalbiy Tuguz ${ }^{2}$ \\ ${ }^{1}$ Don State Technical University, Gagarin square, 1, Rostov-on-Don, 344003, Russia \\ ${ }^{2}$ Kuban State Agrarian University named after I.T. Trubilin, Kalinina str., 13, 350044 Krasnodar, \\ Russia
}

\begin{abstract}
The article highlights issues related to the study of the approach to assessing and analyzing the risks of agricultural enterprises. An approach to conducting a full-fledged comprehensive analysis of risks and factors influencing them with the help of indicators for assessing financial performance is described. An algorithm for assessing risks based on calculating the dependence of the size of assets, the margin of financial strength and the leverage of production leverage and its effect is considered. The methodology and results of research on the practical study of farms in the Krasnodar Territory in terms of the level of financial strength in grain products and cattle meat are presented. Conclusions are made about the degree of risk exposure of these types of industries, the features of the results of diversification in agriculture are revealed.
\end{abstract}

\section{Introduction}

To ensure the effective functioning of agricultural enterprises in the context of the development of a modern economic system, it is important to carry out a systematic analys is of the risks of their functioning, including studying and assessing the possible results of the impact of risks on the organization and management of production in the agricultural sector [1-4].

Analysis of the works of modern researchers [5-8] showed a more acceptable way to analyze the risks of their management using financial indicators of agricultural enterprises. In the course of the study, a set of financial indicators was formed, such as production leverage, financial strength margin and the effect of production leverage [9-12], which make it possible to assess the degree of risk impact on the efficiency of agricultural enterprises.

As a result of the study, it was concluded that the most significant risk factors are internal factors of production, presented on the basis of an analysis of a sample of agricultural enterprises in the Krasnodar Territory specializing in the production of grain and cattle meat. [13-16]. In connection with the above result of the study, it is that the features of the results of diversification in agriculture were identified and substantiated.

The aim of the study is to develop an approach to assessing the risk of agricultural enterprises based on financial performance indicators, as well as a practical study of the factors affecting its actual value.

\footnotetext{
*Corresponding author: carinaba@yandex.ru
} 


\section{Materials and methods}

With the transition to a market economy, a free choice of types and directions of economic activity, independence in managing an organization led to an increased level of responsibility for ensuring the sustainable functioning of an agricultural organization. This has led to the prioritization of risk and the need to manage it.

In practical calculations, to determine the risk, margin analysis is used, the ratio of the so-called gross margin (the result from sales after reimbursement of variable costs) to profit. The strength of the influence of the production leverage depends on the relative magnitude of fixed costs [6]. The introduction of production automation in agriculture leads to a relative increase in fixed costs and, accordingly, to a decrease in the share of variable costs in the unit cost. This circumstance affects the gross margin ratio, the threshold of profitability and other elements of operational analysis in different ways (Table 1).

Table 1. Level and dynamics of key indicators of risk analysis of agricultural enterprises, Source: [59].

\begin{tabular}{|l|c|c|l|}
\hline \multicolumn{1}{|c|}{ Index } & $\begin{array}{c}\text { Capital } \\
\text { intensification } \\
\text { (automation) }\end{array}$ & $\begin{array}{c}\text { Intensification } \\
\text { of direct labor }\end{array}$ & Comments \\
\hline Production lever & Above & $\begin{array}{l}\text { Operational leverage as a } \\
\text { measure of involving fixed } \\
\text { cost in automated } \\
\text { manufacturing }\end{array}$ \\
\hline $\begin{array}{l}\text { General level of risk } \\
\text { associated with } \\
\text { business activities }\end{array}$ & Above & Below & $\begin{array}{l}\text { The risk factor accumulates } \\
\text { all of the above factors }\end{array}$ \\
\hline Gross margin ratio & Above & Below & $\begin{array}{l}\text { Variable costs in automated } \\
\text { manufacturing are relatively } \\
\text { lower }\end{array}$ \\
\hline $\begin{array}{l}\text { Range of acceptable } \\
\text { management solutions }\end{array}$ & Narrower & Wider & $\begin{array}{l}\text { With high fixed costs in } \\
\text { automated production, } \\
\text { management is more } \\
\text { "locked", that is, it has fewer } \\
\text { options for choosing } \\
\text { solutions }\end{array}$ \\
\hline Financial safety margin & Below & Above & $\begin{array}{l}\text { Due to the higher } \\
\text { profitability threshold in } \\
\text { automated manufacturing, } \\
\text { the financial safety margin is } \\
\text { usually lower }\end{array}$ \\
\hline
\end{tabular}

Thus, it is clear that the risk assessment in terms of production leverage is the most appropriate for most agricultural enterprises.

\section{Results}

Risks in the financial activities of agricultural enterprises, in contrast to production, supply and other types of activities, are more difficult to assess directly due to the lack of generalizing indicators or the impossibility of quantitative measurement. To determine the level of solvency, it is necess ary to find out the size and structure of the organization's debt, to determine the possibility of covering it.

Solvency must be determined in order to find out what share of its debts and in what time frame the organization can repay. The first step in determining it is the calculation of 
the solvency ratios, which are calculated subject to the availability of own funds, settlement with debtors, sale of working capital, etc.

To establish the degree of solvency on average per farm in the Krasnodar Territory, consider the solvency indicators. The results of calculations on average per 1 farm in the region are shown in Table 2.

Table 2. Maturities dates in months due to sales proceeds (on average per 1 farm in Krasnodar Territory).

\begin{tabular}{|l|c|c|c|c|c|c|}
\hline \multicolumn{1}{|c|}{ Indicators } & $\mathbf{2 0 1 6}$ & $\mathbf{2 0 1 7}$ & $\mathbf{2 0 1 8}$ & $\mathbf{2 0 1 9}$ & $\mathbf{2 0 2 0}$ & $\begin{array}{c}\text { Changes for } \\
\text { the period }\end{array}$ \\
\hline $\begin{array}{l}\text { 1. Degree of total } \\
\text { solvency, months }\end{array}$ & 16.6 & 15.9 & 11.9 & 9.7 & 10.6 & -6 \\
\hline $\begin{array}{l}\text { 2. Ratio of debt on loans } \\
\text { and borrowings, months }\end{array}$ & 2.9 & 2.4 & 2.9 & 3.2 & 4.0 & 1.1 \\
\hline $\begin{array}{l}\text { 3. Ratio of debt to other } \\
\text { enterprises, months }\end{array}$ & 4.4 & 4.3 & 3.0 & 3.0 & 3.5 & -0.9 \\
\hline $\begin{array}{l}\text { 4. Coefficient of debt to } \\
\text { fhe fiscal system, } \\
\text { months. }\end{array}$ & 8.2 & 7.9 & 5.0 & 2.8 & 2.6 & -5.6 \\
\hline $\begin{array}{l}\text { 5. Coefficient of internal } \\
\text { debt, months. }\end{array}$ & 1.1 & 1.3 & 1.0 & 0.3 & 0.2 & -0.9 \\
\hline $\begin{array}{l}\text { 6. The coefficient of } \\
\text { autonomy (financial } \\
\text { independence) }\end{array}$ & 0.7 & 0.6 & 0.6 & 0.6 & 0.6 & -0.1 \\
\hline
\end{tabular}

Thus, the analysis of this table showed that, despite the restructuring of a significant part of debt obligations, farms still have debts for all types of payments, although the terms of its possible repayment have somewhat decreased [10].

For a full-fledged comprehensive analysis of financial risk and the factors influencing it, first of all, the main indicators characteristic of marginal analysis were calculated, which serves as the most effective method of fin ancial analysis for the purpose of operational and strategic planning, tracking the dependence of financial results on costs and production volumes. Table 3 shows the dependence on the ratio of fixed and variable costs presented in the table of indicators.

The calculation results show problem areas in the activities of the studied organizations. So, with an increase in fixed costs in relation to variables, both revenue and profit from sales, and gross margin, and the threshold of profitability, and the margin of financial strength decrease [11].

Table 3. Dependence of performance on the value of the ratio of fixed and variable.

\begin{tabular}{|c|c|c|c|c|c|c|c|}
\hline \multirow[b]{2}{*}{$\begin{array}{c}\text { Group } \\
\text { no. }\end{array}$} & \multirow{2}{*}{$\begin{array}{c}\text { Fixed } \\
\text { costs to } \\
\text { variables } \\
, \%\end{array}$} & \multirow{2}{*}{$\begin{array}{c}\text { Number } \\
\text { of } \\
\text { organizat } \\
\text { ions in } \\
\text { the } \\
\text { group }\end{array}$} & \multicolumn{5}{|c|}{ On average for 1 organization, thous and rubles } \\
\hline & & & $\begin{array}{c}\text { Sales } \\
\text { revenue }\end{array}$ & $\begin{array}{l}\text { Profit } \\
\text { (loss) } \\
\text { from } \\
\text { sales } \\
\end{array}$ & $\begin{array}{c}\text { Gross } \\
\text { margin }\end{array}$ & $\begin{array}{l}\text { Profitabilit } \\
\text { y threshold }\end{array}$ & $\begin{array}{c}\text { Financial } \\
\text { safety margin }\end{array}$ \\
\hline 1 & До 5 & 8 & 17274.00 & 401.50 & 1050.25 & 62473.10 & -45199.10 \\
\hline 2 & $5-10$ & 20 & 32210.85 & 3267.85 & 5151.80 & 17232.48 & 14978.37 \\
\hline 3 & $10-15$ & 13 & 19753.08 & 2744.08 & 4591.62 & 11067.73 & 8685.35 \\
\hline
\end{tabular}




\begin{tabular}{|c|c|c|c|c|c|c|c|}
\hline 4 & $15-20$ & 7 & 8307.86 & 933.29 & 2043.43 & 4852.03 & 3455.82 \\
\hline 5 & Over 20 & 13 & 4632.08 & 338.62 & 1270.46 & 8677.83 & -4045.75 \\
\hline \multicolumn{2}{|c|}{ Total for the sample } & 61 & 18976.57 & 1888.15 & 3310.64 & 18608.05 & 368.53 \\
\hline
\end{tabular}

The described tendency is typical for the overwhelming majority of organizations represented in the group, with the exception of several atypical organizations of the first group, which are characterized by a ratio of less than $5 \%$.

Thus, it is obvious that with an increase in production leverage (over 10\%), both the results of the organization's activities and financial stability (margin of financial strength) deteriorate. Analysis of the average initial data on the ratio of fixed and variable costs is presented in Table 4.

Table 4. Average initial data on the ratio of fixed and variable costs from the value of the ratio of fixed and variable costs.

\begin{tabular}{|c|c|c|c|c|c|c|}
\hline \multirow{2}{*}{$\begin{array}{c}\text { Group } \\
\text { no. }\end{array}$} & \multirow{2}{*}{$\begin{array}{c}\text { Fixed costs } \\
\text { to } \\
\text { variables, } \%\end{array}$} & $\begin{array}{c}\text { Number of } \\
\text { organizations } \\
\text { in the group }\end{array}$ & $\begin{array}{c}|c| \\
\text { Cost of } \\
\text { products sold }\end{array}$ & Variable costs & Fixed costs & $\begin{array}{c}\text { Share of fixed } \\
\text { costs in prime } \\
\text { cost, } \%\end{array}$ \\
\hline 1 & To 5 & 8 & 16872.50 & 16223.75 & 648.75 & 3.84 \\
\hline 2 & $5-10$ & 20 & 28943.00 & 27059.05 & 1883.95 & 6.5 \\
\hline 3 & $10-15$ & 13 & 17009.00 & 15161.46 & 1847.54 & 10.86 \\
\hline 4 & $15-20$ & 7 & 7374.57 & 6264.43 & 1110.14 & 15.05 \\
\hline 5 & Over 20 & 13 & 4293.46 & 3361.62 & 931.85 & 21.7 \\
\hline \multicolumn{2}{|c|}{ Total for the sample } & 61 & 17088.43 & 15665.93 & 1422.49 & 8.32 \\
\hline
\end{tabular}

According to Table 4, there is a tendency to decrease the absolute average values for groups of both fixed and variable costs with an increase in the leverage of production leverage.

Thus, it can be assumed that there is an inverse relationship between the size of organizations, which partly characterizes both the cost, and the ratio of fixed and variable costs.

To confirm or refute the assumption made, let us analyze the data presented in Tables 5 and 6.

Table 5. Dependence of the size of assets and the leverage of production leverage.

\begin{tabular}{|c|c|c|c|c|c|c|}
\hline & \multirow{2}{*}{$\begin{array}{c}\text { Fixed } \\
\text { Group } \\
\text { no. }\end{array}$} & \multirow{2}{*}{$\begin{array}{c}\text { Number of } \\
\text { variables, } \\
\text { organization } \\
\text { s in the } \\
\text { group }\end{array}$} & $\begin{array}{c}\text { Specialization } \\
\text { rate }\end{array}$ & $\begin{array}{c}\text { Total } \\
\text { assets }\end{array}$ & $\begin{array}{c}\text { Working } \\
\text { capital }\end{array}$ & $\begin{array}{c}\text { On average for 1 organization, thous and rubles } \\
\text { circulating } \\
\text { funds }\end{array}$ \\
\hline 1 & To 5 & 8 & 0,55 & 17111,00 & 13369,50 & 4276,00 \\
\hline 2 & $5-10$ & 20 & 0,35 & 51920,30 & 23311,40 & 28608,90 \\
\hline 3 & $10-15$ & 13 & 0,39 & 43345,00 & 23079,54 & 20265,46 \\
\hline 4 & $15-20$ & 7 & 0,35 & 15010,71 & 6024,71 & 8986,00 \\
\hline 5 & Over 20 & 13 & 0,45 & 12282,62 & 3887,77 & 9094,42 \\
\hline
\end{tabular}




$$
61
$$

0,41

32844,72

15834,95

17586,37

According to Table 5, it can be seen that the size of both circulating and non-circulating assets decreases with increasing leverage, there is no connection with the coefficient of specialization.

Table 6 presents data on the main components of the production potential of organizations, which characterize their size.

Table 6. Dependence of the size of assets and the leverage of production leverage.

\begin{tabular}{|c|c|c|c|c|c|c|c|}
\hline \multirow[b]{2}{*}{$\begin{array}{c}\text { Group } \\
\text { no. }\end{array}$} & \multirow{2}{*}{$\begin{array}{c}\text { Fixed } \\
\text { costs to } \\
\text { variables, } \\
\%\end{array}$} & \multirow{2}{*}{$\begin{array}{l}\text { Number of } \\
\text { organizations } \\
\text { in the group }\end{array}$} & \multicolumn{5}{|c|}{ On average for 1 organization, thousand rubles } \\
\hline & & & $\begin{array}{c}\text { Number of } \\
\text { employees, } \\
\text { people }\end{array}$ & $\begin{array}{l}\text { Fixed } \\
\text { assets, } \\
\text { thousand } \\
\text { rubles }\end{array}$ & $\begin{array}{c}\text { Farmland } \\
\text { area, ha }\end{array}$ & $\begin{array}{l}\text { Arable } \\
\text { land, ha }\end{array}$ & $\begin{array}{c}\text { Conditional } \\
\text { livestock, } \\
\text { head }\end{array}$ \\
\hline 1 & To 5 & 8 & 78 & 9831,14 & 5166,00 & 4749,43 & 206 \\
\hline 2 & $5-10$ & 20 & 150 & 45494,45 & 4871,75 & 4326,25 & 649 \\
\hline 3 & $10-15$ & 13 & 114 & 26600,38 & 5064,50 & 4338,50 & 630 \\
\hline 4 & $15-20$ & 7 & 46 & 9513,00 & 2575,43 & 2132,14 & 315 \\
\hline 5 & Over 20 & 13 & 41 & 15166,83 & 2580,92 & 1894,75 & 229 \\
\hline \multicolumn{2}{|c|}{ Total for the sample } & 61 & 98 & 26662,80 & 4196,03 & 3611,98 & 503 \\
\hline
\end{tabular}

These tables also confirm the assumption made about the inverse relationship between the size of the organization and the leverage of production.

The "dead center" (or critical sales volume) method as applied to assessing and predicting the effect of leverage consists in determining for each specific situation the volume of output that ensures break-even activity.

\section{Discussion of the results}

For a comprehensive analysis of the level of financial strength, the influence of a number of factors on this indicator was analyzed [12].

The object of the study was 100 farms from different districts of the Krasnodar Territory.

Consider the relationship between the level of financial strength in the economy as a whole with the main performance results. The data are presented in Table 7.

Table 7. Grouping of farms by the level of financial strength (on average for 1 organization).

\begin{tabular}{|c|c|c|c|c|c|c|}
\hline \multirow{2}{*}{$\begin{array}{c}\text { Group } \\
\text { no. }\end{array}$} & \multirow{2}{*}{$\begin{array}{c}\text { ZFP } \\
\text { level,\% }\end{array}$} & $\begin{array}{c}\text { Number of } \\
\text { organizations } \\
\text { in the group }\end{array}$ & $\begin{array}{c}\text { Sales } \\
\text { revenue }\end{array}$ & $\begin{array}{c}\text { Profit } \\
\text { (loss) } \\
\text { from sales }\end{array}$ & $\begin{array}{c}\text { On average for 1 organization, thous and rubles } \\
\text { Profitability }\end{array}$ & $\begin{array}{c}\text { Specialization } \\
\text { ratio }\end{array}$ \\
\hline 1 & To 0 & 54 & 5582.0 & -977.5 & -0.31 & 0.413 \\
\hline 2 & $1-20$ & 5 & 7049.2 & 74.0 & 0.01 & 0.362 \\
\hline 3 & $21-40$ & 13 & 10183.7 & 361.5 & 0.03 & 0.404 \\
\hline 4 & Over 40 & 28 & 30246.0 & 4186.0 & 0.15 & 0.427 \\
\hline \multicolumn{2}{|c|}{ Total for the sample } & 100 & 13159.5 & 694.9 & -0.12 & 0.413 \\
\hline
\end{tabular}


Thus, based on the above, we can conclude that despite the fact that a small organization is considered predominant over a large one, reality proves something completely different.

The objective modern need of the economy for the concentration and centralization of production and capital has convincingly proved the need to enlarge agricultural organizations.

The margin of financial strength, calculated for the economy as a whole, does not allow us to identify the role of certain types of products in shaping the result from sales.

This can be done by calculating the threshold of profitability for certain types of products, which account for a larger share in the total volume of products sold, in agriculture, such products include: grain, cattle meat and milk.

The grouping of farms by the level of financial strength, calculated by grain, is presented in Table 8 .

Table 8. Grouping of farms by the level of financial strength in grain products (on average per farm).

\begin{tabular}{|c|c|c|c|c|c|c|c|c|}
\hline \multirow{3}{*}{$\begin{array}{c}\text { Group } \\
\text { no. }\end{array}$} & \multirow{3}{*}{$\begin{array}{c}\text { ZFP } \\
\text { level,\% }\end{array}$} & \multirow{3}{*}{$\begin{array}{l}\text { Number } \\
\text { of } \\
\text { organiza } \\
\text { tions in } \\
\text { the } \\
\text { group }\end{array}$} & \multicolumn{6}{|c|}{ On average for 1 organization } \\
\hline & & & \multirow{2}{*}{$\begin{array}{c}\text { Sales } \\
\text { revenue, } \\
\text { thousand } \\
\text { rubles }\end{array}$} & \multirow{2}{*}{$\begin{array}{c}\text { Total } \\
\text { realized } \\
\text {,c }\end{array}$} & \multirow{2}{*}{$\begin{array}{c}\text { Selling } \\
\text { price, rub. }\end{array}$} & \multirow{2}{*}{$\begin{array}{c}\text { Cost } \\
\text { price, } \\
\text { rub. }\end{array}$} & \multicolumn{2}{|c|}{$\begin{array}{c}\text { Profitability } \\
\text { threshold }\end{array}$} \\
\hline & & & & & & & Centner & $\begin{array}{c}\text { Thousan } \\
\text { d } \\
\text { roubles }\end{array}$ \\
\hline 1 & To 0 & 46 & 16753 & 6164,1 & 263,2 & 407,9 & - & - \\
\hline 2 & $1-20$ & 4 & 7677,8 & $\begin{array}{c}25 \\
952,3\end{array}$ & 2903 & 286,5 & 22465,2 & 6670,2 \\
\hline 3 & $21-40$ & 8 & 3738,8 & $\begin{array}{c}14 \\
705,6 \\
\end{array}$ & 257,5 & 248,2 & 10349,5 & 2626,0 \\
\hline 4 & Over 40 & 37 & 6848,5 & $\begin{array}{c}25 \\
562,9 \\
\end{array}$ & 257,4 & 208,9 & 7826,4 & 2045,2 \\
\hline \multicolumn{2}{|c|}{$\begin{array}{c}\text { Total for the } \\
\text { sample }\end{array}$} & 95 & 4116,6 & $\begin{array}{c}15 \\
271,9\end{array}$ & 261,6 & 311,8 & 9433,4 & 2517,6 \\
\hline
\end{tabular}

The analysis showed that with an increase in the margin of financial strength, there is an increase in such indicators as sales proceeds and product sales.

Thus, under the current conditions, even the grain industry, which is considered to be the most profitable, is exposed to risk due to the instability of grain prices and an increase in the cost of its production, due to the growth of both fixed and variable costs [13].

In addition to grain, the production direction of the organization is determined by cattle meat and milk, the calculation for which is presented in Tables 9 and 10.

Table 9. Grouping of farms by the level of financial strength of cattle meat (on average per farm).

\begin{tabular}{|c|c|c|c|c|c|c|c|c|}
\hline \multirow[b]{2}{*}{$\begin{array}{c}\text { Group } \\
\text { no. }\end{array}$} & \multirow[b]{2}{*}{$\begin{array}{c}\text { ZFP } \\
\text { level,\% }\end{array}$} & \multirow{2}{*}{$\begin{array}{l}\text { Number } \\
\text { of } \\
\text { organiza } \\
\text { tions in } \\
\text { the } \\
\text { group }\end{array}$} & \multicolumn{4}{|c|}{ On average for 1 organization } & \multicolumn{2}{|c|}{$\begin{array}{c}\text { Profitability } \\
\text { threshold }\end{array}$} \\
\hline & & & $\begin{array}{l}\text { Sales } \\
\text { revenue, } \\
\text { thousan } \\
\text { d rubles }\end{array}$ & $\begin{array}{c}\text { Total } \\
\text { realized, } \mathrm{c}\end{array}$ & $\begin{array}{c}\text { Selling } \\
\text { price, } \\
\text { rub. }\end{array}$ & $\begin{array}{c}\text { Cost } \\
\text { price, } \\
\text { rub }\end{array}$ & Cent. & $\begin{array}{l}\text { Thousan } \\
\text { d roubles }\end{array}$ \\
\hline 1 & To 0 & 54 & 1873,6 & 542,4 & 3566,2 & 5235,2 & - & - \\
\hline 2 & $1-20$ & 2 & 450,0 & 145,5 & 4134,0 & 4093,1 & 133,2 & 410,0 \\
\hline 3 & $21-40$ & 2 & 9185,5 & 2232,5 & 4013,7 & 3896,6 & 171,33 & 7058,0 \\
\hline 4 & Over 40 & 9 & 2983,3 & 666,0 & 4896,9 & 3472,3 & 166,7 & 3305,9 \\
\hline \multicolumn{2}{|c|}{ Total for the sample } & 67 & 2198,5 & 597,6 & 3775,2 & 49243 & 399,47 & 1657,5 \\
\hline
\end{tabular}


The analysis showed that with an increase in the margin of financial strength, there is an increase in indicators such as sales proceeds, product sales and the sales price of 1 cent. The organizations of the first group have not reached the threshold of profitability either in physical terms or in monetary terms. For the other three groups, this indicator is increasing.

Table 10. Totals by farm groupings.

\begin{tabular}{|c|c|c|c|c|c|c|}
\hline $\begin{array}{c}\text { Group } \\
\text { no. }\end{array}$ & $\begin{array}{c}\text { ZFP } \\
\text { level,\% }\end{array}$ & $\begin{array}{c}\text { Number of } \\
\text { organizations } \\
\text { (total) }\end{array}$ & $\begin{array}{c}\text { Number of } \\
\text { organizations } \\
\text { (grain) }\end{array}$ & $\begin{array}{c}\text { In \% to } \\
\text { the } \\
\text { total }\end{array}$ & $\begin{array}{c}\text { Number of } \\
\text { organizations } \\
\text { (cattle meat) }\end{array}$ & $\begin{array}{c}\text { In\% to } \\
\text { the total }\end{array}$ \\
\hline 1 & To 0 & 54 & 46 & 48,4 & 54 & 80,6 \\
\hline 2 & $1-20$ & 5 & 4 & 4,2 & 2 & 3,0 \\
\hline 3 & $21-40$ & 13 & 8 & 8,4 & 2 & 3,0 \\
\hline 4 & Over 40 & 28 & 37 & 39,0 & 9 & 13,4 \\
\hline \multicolumn{2}{|r|}{ Total for the sample } & 100 & 95 & 100,0 & 67 & 100,0 \\
\hline
\end{tabular}

Thus, the most at risk is the production and sale of cattle meat, the less risky is the production and sale of grain.

The analysis of the structure of marketable products of organizations of the Krasnodar Territory for 2020 showed that the main products of specialization of farms are grain, cattle meat. On average, they account for about 55\% of marketable products [14]. Changes in the structure of commercial products are associated, first of all, not with changes in priorities, but with a low level of crop production, in some years, due to unfavorable weather conditions.

\section{Conclusions}

The results of the study showed that the most preferable for organizations of the Krasnodar Territory is the plant growing industry in general and grain specialization, in particular. However, the introduction of grain specialization that is optimal, from the point of view of the planned level of profitability, in real economic conditions can lead to negative consequences in the regional economy and losses in the economy, to an increase in risk factors.

The conducted research has shown how significant is the influence of internal factors on the level of risk [15-16]. So, as a criterion for assessing the magnitude of risk were taken indicators such as the leverage of production leverage, the financial strength of the organization and the actual effect of production leverage. When justifying the advisability of using a margin of financial strength, the following provisions should be adhered to:

- the likelihood of incurring losses is higher for those economic entities whose financial strength is less;

- with an insignificant margin of financial strength, any failure in the entrepreneurial activity of the organization will lead to a loss of revenue;

- a decrease in revenue for many organizations means that they will not be able to achieve a critical volume of sales and the result of their activities will be a loss.

In connection with the above study result, it is that the features of the results of diversification in agriculture have been identified. So, if traditionally it is believed that more diversi fied production is less exposed to risk and more sustainable, then in agriculture, excessive diversification, on the contrary, leads to a deterioration in the results of activities in comparison with mono-specialized organizations. Thus, diversification, an important risk reduction method, must be used with caution in agriculture. 


\section{References}

1. H. Wang, J. Zhou, Y. T ang, Z. Liu, A. Kang, B. Chen, Flood econo mic assess ment of st ructural me asure based on integrated flood risk management: A case study in Beijing. Journal of Environmental Management 280, 111701 (2021) doi.org/10.1016/j.jenvman.2020.111701

2. Y. Ma, S. Mummullage, B. Wijesiri, P. Egodawatta, J. McGree, G. A.Ayoko, A. Goonetilleke, Source quantification and risk assess ment as a foundation for risk man agement of met als in urb an road depos ited solids. Journal of Hazardous M aterials 408, 124912 (2021) doi.org/10.1016/j.jhazmat.2020.124912

3. H. H. Lien, Y. Mey, S. R.Bush, M. P.M. Meuwissen, A socio-sp atial inde $\mathrm{x}$ for risk m anagement in shrimp aquaculture ac ross landsc apes, Aquacu lture 531, 735861 (2021) doi.org/10.1016/j.aquaculture.2020.735861

4. A. Murata, Cultural aspects as a root $\mathrm{c}$ ause of org anizational failure in risk and c risis manage ment in the Fu kushima Da iichi disaster, Safety Scie nce 135, 105091 (2021) doi.org/10.1016/j.ssci.2020.105091

5. S.-S. Lin, S.-L. Shen, A. ZhoucYe-Shuang Xu, Risk assess ment and management of excavation system based on fuzzy set theory and machine learn ing methods, Automation in Construct ion 122, 103490 (2021) doi.org/10.1016/j.autcon.2020.103490

6. J. Hallikas, K. Lintukangas, A.-KaisaKähkönen, The effects of sustainab ility pract ices on the performance of risk management and purchasing, Jou rnal of Cleaner Product ion 263, 121579 (2020) doi.org/10.1016/j.jclepro.2020.121579

7. M. Neisi, M. Bijani, E. Abbasi, H. Mahmoudi, H. Azadi, Analyzing farmers' droug ht risk ma nagement be havior: Evidence from Iran, Journal of Hyd rology 590, 125243 (2020)

8. F. Brocal, N. Paltrinieri, C. González-Gaya, M.A. Sebastián, G. Reniers, Approach to the selection of strateg ies for eme rging risk m anagement co nsidering uncertainty as the main decision variable in occup ational contexts, Safety Science 134, 105041 (2021) doi.org/10.1016/j.jc lepro.2018.0 3.023

9. Jheng-Guo Chen, Yao-Zhao Zhong, Laurence Zsu-Hsin Chuang, Bärbel Koppe, Hwa Chien, Risk manage ment of co astal wate $r$ safety for recreatio nal activit ies: The $c$ ase of Taoyuan coast, Applied Geography 117, 102173, (2020) doi.org/10.1016/j.apgeog.2020.102173

10. T. Parhizkara, S. Hogenboom, J. E. Vinnem, I. B. Utne, Data drive n approach to r isk manage ment and dec ision support for dyn amic positioning syste ms, Safety 201, 106964 (2020) doi.org/10.1016/j.ress.2020.106964

11. V. Vujović, N. Denić, V. Stevanović, and etc., Project pl anning and risk manage ment as a success factor for IT projects in ag ricultural schools in Se rbia, Technology in Society 63, 101371 (2020) doi.org/10.1016/j.techsoc.2020.101371

12. F. Fathi, A. Sheikhzeinoddin, R. Talebnejad, Environmental and economic risk manage ment of seed maize product ion in Ira n, Journal of Cleaner Product ion 258, 120772 (2020) doi.org/10.1016/j.jclepro.2020.120772

13. K.A. Barmuta, E.M. Akhmetshin, I.Y. Andryushchenko, G.V. Meshkova, A.O. Zekiy, Problems of business processes transformation in the context of building digital economy. Entrepreneurship and Sustainability Issues 8(1), 945-959 (2020)

14. V.V. Mazur, K.A. Barmuta, S.S. Demin, E.A. Tikhomirov, M.A. Bykovskiy, Innovation clusters: Advantages and disadvantag. International Journal of Economics and F inancial Issues 6(1S), 270- 274 (2016) 
15. K. Barmuta, V. Ponkratov, M. Maramygin, N. Kuznetsov, V. Ivlev, M. Ivleva, Mathematical mode 1 of optim izing the $b$ alance sheet st ructure of the Russian $b$ anking syste $\mathrm{m}$ with allow ance for the foreign exchange ris k levels. Entrepreneu rship and Sust ainability Issues, 7(1), 484-4 97 (2019), doi: 10.9770/jes i.7.1(34)

16. N. S. Plaskova, N. A. Prodanova, A. S. Samusenko, E. A. Erzinkyan, K. Barmuta, R. A. Shichiyakh, Investment dec isions for mation: In novative assets. Internation al Journal of Engineering and Advanced Technology 9(1), 2913-2916 (2019) do i:10.35940/ijeat.A1213.109119 